\title{
PREDICTION OF POLLUTANTS EMISSIONS DISPERSION OF PHOSPHATE FERTILIZERS PRODUCTION FACILITY
}

\author{
Hamdi A. Abdel Salam \\ Department of Mechanical Power Engineering, Mansoura University, Mansoura, Egypt 33516 \\ Email: eedc_eg@yahoo.com; Tel: +2-012-22181181; Fax:+2-050-2248585
}

\begin{abstract}
This study aims to the prediction of pollutants emissions dispersion of a $1 \mathrm{M} \cdot$ ton/year phosphate fertilizer facility, which is located at El-Menya Governorate, Egypt. ALOHA air dispersion software is used to predict the pollutant emissions dispersion from different stacks in the proposed project. The estimated total pollutant emissions from the proposed project are $3180 \mathrm{~g} / \mathrm{m}^{3}$ of hydrogen fluoride $(\mathrm{HF}), 72000 \mathrm{~g} / \mathrm{m}^{3}$ of sulfur dioxide $\left(\mathrm{SO}_{2}\right), 14700 \mathrm{~g} / \mathrm{m}^{3}$ of sulfur tri-oxide $\left(\mathrm{SO}_{3}\right), 2700 \mathrm{~g} / \mathrm{m}^{3}$ of ammonia $\left(\mathrm{NH}_{3}\right)$, and $53550 \mathrm{~g} / \mathrm{m}^{3}$ of particulates (PM). Based on the total pollutant emissions from the project, the concentrations of the investigated pollution emissions at $0.5 \mathrm{~km}, 1 \mathrm{~km}$ and $2 \mathrm{~km}$ downstream the source at the worst case scenario are obtained and compared with the allowed limits. It has been found that all the emissions resulted from different activities in the proposed project are much lower than the allowed limits specified by the Egyptian ministry of environment in Law 4/1994, and therefore the proposed project is not expected to cause any undesirable impacts on the surrounding environment.
\end{abstract}

Index Terms: Air pollution; Air dispersion modeling; Environmental impact assessment; Phosphate fertilizer industry.

\section{INTRODUCTION}

Phosphate fertilizers are of the most important production elements that play a key role in the agricultural development, especially in major food crops such as wheat and rice. Phosphate fertilizers industry is considered as one of the most important strategic industries which enhance the social development and economic progress. Phosphate fertilizer industry is promising in Egypt due to the availability of basic raw materials needed for the manufacturing processes such as raw rock phosphate. Egypt is ranked the $11^{\text {th }}$ globally in terms of the size of reserves of phosphate by 1000 million tons, with 3 million tons extracted annually [1]. Global markets showed signs of good improvement in trading during 1988 in phosphate ores, with global production of rock phosphate of 165 million tons, then fell to 120 tons per year in 1993 and then improved and reached 160 million tons in 2005. Superphosphate fertilizers are mainly produced in Egypt, Lebanon and Tunisia with total annual production capacity of 1.25 million tons, where $78 \%$ of this capacity is produced in Egypt.

During the manufacturing processes of phosphate fertilizer plants, several air emissions are produced such as hydrogen fluoride (HF), sulfur dioxide $\left(\mathrm{SO}_{2}\right)$, sulfur tri-oxide $\left(\mathrm{SO}_{3}\right)$, ammonia $\left(\mathrm{NH}_{3}\right)$, and particulates (PM). These emissions if produced with high concentrations may lead to the air pollution of surrounding environment [2,3]. In addition, the net impacts from changed scenario of air emission coming out from fertilizer plants activity may cause the degradation of human health and vegetation in and around the area. Several studies have emphasized that localized critical concentrations of pollutants can seriously affect air quality $[4,5]$. Number of chimneys together inside the project site often causes a pollution of the surrounding area which is probably away from the plant several kilometers as well as within the project site, and as such it is possible that chimneys emissions do not represent a direct dangerous inside the site only but it can effect area kilometers away the site [6]. The dispersion of pollutants from different sources using air dispersion models has been identified in several studies [3-12].

In this study, the dispersion of pollutant emissions from different stacks in a 1 M.ton/year phosphate fertilizer facility is studied. The pollutants investigated are hydrogen fluoride (HF), sulfur dioxide $\left(\mathrm{SO}_{2}\right)$, sulfur trioxide $\left(\mathrm{SO}_{3}\right)$, ammonia $\left(\mathrm{NH}_{3}\right)$, and Particulates (PM) emissions. To this aim, several air dispersion models are developed using the ALOHA air dispersion modeling software.

\section{CLIMATIC DESCRIPTION OF THE PROJECT SITE}

The weather data for the location of the proposed project was obtained using the Energy Plus Energy Simulation Software, which was developed by the Department of Energy (DOE) of the US. Fig. 1 shows the annual average 
temperatures, relative humidities and wind speeds for El Minya, Egypt. As Fig. 1(a) shows, the lowest temperature occurs in January, and it is found to be $6^{\circ} \mathrm{C}$. Also, the minimum wind speed occurs in January, as Fig. 1(b) shows, and it is found to be $1.2 \mathrm{~m} / \mathrm{s}$. In order to account for the worst case scenario, both the minimum temperature $\left(6^{\circ} \mathrm{C}\right)$ and wind speed $(1.2 \mathrm{~m} / \mathrm{s})$ will be used in the air dispersion model.

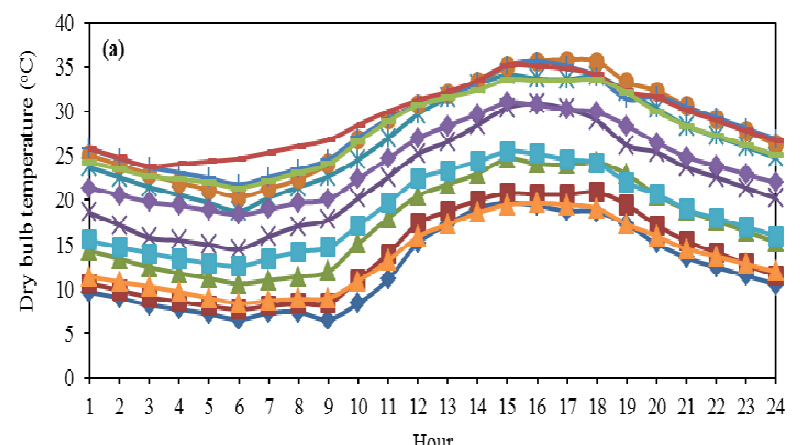

Hour
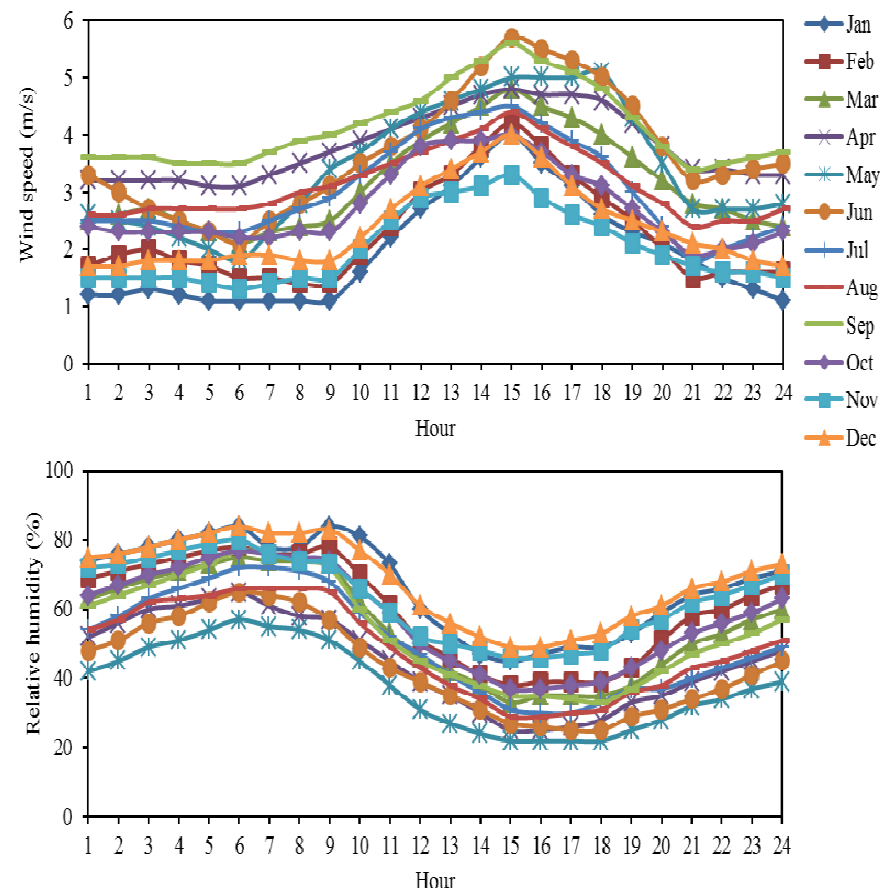

Fig. 1 Annual average hourly (a) temperature, (b) wind speed and (c) relative humidity for El Minya, Egypt.

\section{GEOGRAPHIC DESCRIPTION OF THE} PROJECT SITE

Fig. 2 shows the location of the project site under investigation, which is located in the industrial zone of Elmtahrah at El-Menya Governorate, Egypt. El-Menya is located in the upper part of Egypt between latitudes of $27^{\circ}$ $41^{\prime}$ and $47^{\circ} 28^{\prime}$, and longitudes of $28^{\circ} 32^{\prime}$ and $32^{\circ} 38^{\prime}$. The industrial zone of Elmtahrah is located at about $12 \mathrm{~km}$ southeast of El-Minya with a total area of 1516 acres. Elmtahrah industrial zone is divided into four sectors covering nine industrial groups and arranged according to the degree of pollution level. Table 1 shows the geographic coordinates of the project site.

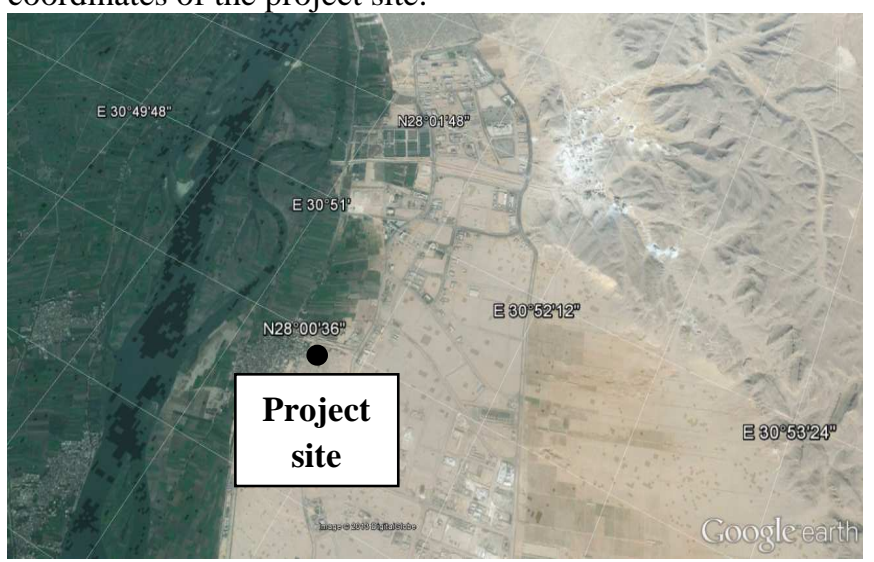

Fig. 2 Location of the project site

Table 1. Geographic coordinates the project site.

\begin{tabular}{|c|c|c|c|c|c|}
\hline Point & \multicolumn{2}{|c|}{$\begin{array}{l}\text { Geographic } \\
\text { coordinates }\end{array}$} & Point & \multicolumn{2}{|c|}{$\begin{array}{l}\text { Geographic } \\
\text { coordinates }\end{array}$} \\
\hline \multirow[b]{2}{*}{1} & $\mathrm{~N} 28^{\circ}$ & $00.976^{\prime}$ & \multirow[b]{2}{*}{6} & $\mathrm{~N} 28^{\circ}$ & $00.766^{\prime}$ \\
\hline & $\mathrm{E} 30^{\circ}$ & $51.573^{\prime}$ & & $\mathrm{E} 30^{\circ}$ & 51.799' \\
\hline \multirow{2}{*}{2} & $\mathrm{~N} 28^{\circ}$ & 00.930 & \multirow{2}{*}{7} & $\mathrm{~N} 28^{\circ}$ & $00.799^{\prime}$ \\
\hline & E $30^{\circ}$ & $51.739^{\prime}$ & & E $30^{\circ}$ & 51.672' \\
\hline \multirow[b]{2}{*}{3} & $\mathrm{~N} 28^{\circ}$ & $00.844^{\prime}$ & \multirow{2}{*}{8} & $\mathrm{~N} 28^{\circ}$ & $00.821^{\prime}$ \\
\hline & $\mathrm{E} 30^{\circ}$ & $51.921^{\prime}$ & & $\mathrm{E} 30^{\circ}$ & 51.666' \\
\hline \multirow{2}{*}{4} & $\mathrm{~N} 28^{\circ}$ & $00.801^{\prime}$ & \multirow{2}{*}{9} & $\mathrm{~N} 28^{\circ}$ & $00.888^{\prime}$ \\
\hline & $\mathrm{E} 30^{\circ}$ & $52.014^{\prime}$ & & E $30^{\circ}$ & 51.642' \\
\hline \multirow{2}{*}{5} & $\mathrm{~N} 28^{\circ}$ & $00.700^{\prime}$ & \multirow{2}{*}{10} & $\mathrm{~N} 28^{\circ}$ & $00.886^{\prime}$ \\
\hline & E $30^{\circ}$ & $51.950^{\prime}$ & & E $30^{\circ}$ & 51.591' \\
\hline
\end{tabular}

\section{POLLUTANT EMISSIONS FROM THE PROJECT}

Table 2 shows the types of pollutants emitted from different units in the proposed project. Table 3 shows the individual emission loads from each unit, and the total emission loads from the project. The expected total emission loads of hydrogen fluoride ( $\mathrm{HF})$, sulfur dioxide $\left(\mathrm{SO}_{2}\right)$, sulfur trioxide $\left(\mathrm{SO}_{3}\right)$, ammonia $\left(\mathrm{NH}_{3}\right)$, and Particulates $(\mathrm{PM})$ emissions from the proposed project are $3180 \mathrm{~g} / \mathrm{m}^{3}, 72000 \mathrm{~g} / \mathrm{m}^{3}$, $14700 \mathrm{~g} / \mathrm{m}^{3}, 2700 \mathrm{~g} / \mathrm{m}^{3}$ and $53550 \mathrm{~g} / \mathrm{m}^{3}$, respectively.

Table 2 Types of pollutants emitted from different units in the project

\begin{tabular}{|c|c|c|c|c|c|c|}
\hline \multirow{2}{*}{ Unit } & \multirow{2}{*}{$\begin{array}{c}\text { Total air } \\
\text { flow rate } \\
\left(\mathrm{m}^{3} / \mathrm{hr}\right)\end{array}$} & $\mathrm{PM}$ & $\mathrm{HF}$ & $\mathrm{NH}_{3}$ & $\mathrm{SO}_{2}$ & $\mathrm{SO}_{3}$ \\
\hline & 120000 & $\checkmark$ & $\checkmark$ & & & \\
\hline SSP & 225000 & $\checkmark$ & $\checkmark$ & & & \\
\hline GSSP & 120000 & $\checkmark$ & $\checkmark$ & & & \\
\hline GTSP & 90000 & $\checkmark$ & & $\checkmark$ & & \\
\hline DAP & 85000 & $\checkmark$ & & & & $\checkmark$ \\
\hline PS & 85000 & $\checkmark$ & $\checkmark$ & & & \\
\hline DCP & 100000 & $\checkmark$ & & & & \\
\hline NPK & 1000 &
\end{tabular}


Table 2 (continue) Types of pollutants emitted from different units in the project

\begin{tabular}{|c|c|c|c|c|c|c|}
\hline \multirow{2}{*}{ Unit } & \multirow{2}{*}{$\begin{array}{c}\text { Total air } \\
\text { flow rate } \\
\left(\mathrm{m}^{3} / \mathrm{hr}\right)\end{array}$} & $\mathrm{PM}$ & $\mathrm{HF}$ & $\mathrm{NH}_{3}$ & $\mathrm{SO}_{2}$ & $\mathrm{SO}_{3}$ \\
\hline & & & & & \\
\hline $\mathrm{H}_{2} \mathrm{SO}_{4}$ & 160000 & $\checkmark$ & & & $\checkmark$ & $\checkmark$ \\
\hline $\mathrm{H}_{3} \mathrm{PO}_{4}$ & 86000 & $\checkmark$ & $\checkmark$ & & & \\
\hline
\end{tabular}

Table 3 Values of pollutants emitted from different units in the project in $\mathrm{g} / \mathrm{hr}$.

\begin{tabular}{|c|c|c|c|c|c|}
\hline Unit & PM & $\mathrm{HF}$ & $\mathrm{NH}_{3}$ & $\mathrm{SO}_{2}$ & $\mathrm{SO}_{3}$ \\
\hline SSP & 6000 & 600 & & & \\
\hline GSSP & 11250 & 1125 & & & \\
\hline GTSP & 6000 & 600 & & & \\
\hline DAP & 4500 & & 2700 & & \\
\hline PS & 4250 & & & & 5100 \\
\hline DCP & 4250 & 425 & & & \\
\hline NPK & 5000 & & & & \\
\hline $\mathrm{H}_{2} \mathrm{SO}_{4}$ & 8000 & & & 72000 & 9600 \\
\hline $\mathrm{H}_{3} \mathrm{PO}_{4}$ & 4300 & 430 & & & \\
\hline $\mathrm{TOTAL}$ & 53550 & 3180 & 2700 & 72000 & 14700 \\
\hline
\end{tabular}

\section{PREDICTION OF THE DISPERSION}

In this study, an air dispersion model (ALOHA software) is used to model the stacks emissions of different production units in the project. The ALOHA software was developed by the Environmental Protection Agency (EPA) of the US. ALOHA plots a footprint, which encompasses the area where the ground-level concentration of a pollutant gas is predicted to be equal to a specific concentration. In ALOHA's footprint plot, the shaded area represents the footprint itself. The lines along both sides of the footprint indicate the amount of uncertainty in the wind direction. The wind rarely blows constantly from any one direction, and when it shifts direction it blows a pollutant cloud in a new direction. The wind direction confidence lines around the footprint enclose the region within which, about 19 times out of 20, the gas cloud is expected to remain. The lower the wind speed, the more the wind changes direction, so as wind speed decreases, the confidence lines become farther apart.

Several parameters of the project should be determined, to be used by the ALOHA model, as follows. (i) The locations of emissions sources, which are described using the latitude, longitude, and elevation. (ii) The atmospheric conditions, which are defined using the ambient air temperature and relative humidity, wind speed and direction, and cloudiness of the sky. (iii) The source description, which are defined using the stack height, and emissions flow rate and temperature. It is worth mentioning that the aforementioned parameters were determined in this study based on the worst case scenario. For instance, the ambient air temperature was assumed to be $6^{\circ} \mathrm{C}$ due to the fact that the lower the ambient air temperature, the more dangerous are the emissions. Similarly, the wind speed was assumed to be $1.2 \mathrm{~m} / \mathrm{s}$ because the dilution of the emissions in the ambient air becomes lower at low wind speeds. In addition, the flow rates of the emissions were assumed to be at their peak values.

\section{RESULTS AND DISCUSSIONS}

In this section, the dispersion of the $\mathrm{HF}, \mathrm{SO}_{2}, \mathrm{SO}_{3}, \mathrm{NH}_{3}$, and $\mathrm{PM}$ emissions at the worst case scenario are presented. The yellow, orange and red shaded areas in the presented figures show the footprints where the ground level concentrations of the emitted emissions reach certain values. The yellow, orange and red confidence lines show $95 \%$ of the areas that are expected to be exposed to the mentioned concentrations if any unexpected change occurs in the direction of the wind. As mentioned previously, the confidence lines bound the areas in which different concentrations of gas cloud are 95\% likely to remain, given expected amount of fluctuation in wind direction.

Fig. 3 shows the concentration of the HF emissions that are expected to result within $2 \mathrm{~km}$ downstream the source from the following units: SSP, GSSP, GTSP, DCP and $\mathrm{H}_{3} \mathrm{PO}_{4}$. It is clear that the HF depletes as it goes further downstream the source point. The concentration of the emitted HF is $0.042 \mathrm{mg} / \mathrm{m}^{3}(0.84 \%$ of allowed limit) at $0.5 \mathrm{~km}$ away from the source point, and it decreases to $0.027 \mathrm{mg} / \mathrm{m}^{3}(0.54 \%$ of allowed limit) and $0.0112 \mathrm{mg} / \mathrm{m}^{3}(0.22 \%$ of allowed limit) at $1 \mathrm{~km}$ and $2 \mathrm{~km}$, respectively, downstream the source point.

The concentrations of $\mathrm{SO}_{2}$ emissions, which are expected to result within $2 \mathrm{~km}$ around the source from the $\mathrm{H}_{2} \mathrm{SO}_{4}$ unit, are shown in Fig. 4. It is found that the $\mathrm{SO}_{2}$ concentrations at $0.5 \mathrm{~km}$ downstream the source point is $0.95 \mathrm{mg} / \mathrm{m}^{3}$ $\left(0.21 \%\right.$ of allowed limit), and it decreases to $0.6 \mathrm{mg} / \mathrm{m}^{3}$ $(0.13 \%$ of allowed limit) at $1 \mathrm{~km}$. Moreover, it is found that the concentration of the $\mathrm{SO}_{3}$ at $2 \mathrm{~km}$ downstream the source point is $0.26 \mathrm{mg} / \mathrm{m}^{3}(0.06 \%$ of allowed limit).

Fig. 5 shows the concentrations of the $\mathrm{SO}_{3}$ emissions within $2 \mathrm{~km}$ downstream the source which expected to result from the PS and $\mathrm{H}_{2} \mathrm{SO}_{4}$ production units. It is clear that the concentration of the $\mathrm{SO}_{3}$ is $0.19 \mathrm{mg} / \mathrm{m}^{3}(0.33 \%$ of allowed limit) at $0.5 \mathrm{~km}, 0.13 \mathrm{mg} / \mathrm{m}^{3}$ (0.21\% of allowed limit) at 1 $\mathrm{km}$, and $0.05 \mathrm{mg} / \mathrm{m}^{3}(0.09 \%$ of allowed limit $)$ at $2 \mathrm{~km}$, downstream the source point.

Fig. 6 shows the concentrations of $\mathrm{NH}_{3}$ emissions within 2 $\mathrm{km}$ downstream the sources that are expected to result from the DAP unit. The concentration of $\mathrm{NH}_{3}$ emissions is found to be $0.036 \mathrm{mg} / \mathrm{m}^{3}(0.12 \%$ of allowed limit $)$ at $0.5 \mathrm{~km}$ downstream the source point and it decreases to 0.023 $\mathrm{mg} / \mathrm{m}^{3}(0.08 \%$ of allowed limit $)$ at $1 \mathrm{~km}$, and it goes down to $0.01 \mathrm{mg} / \mathrm{m}^{3} \quad(0.03 \%$ of allowed limit $)$ at $2 \mathrm{~km}$, downstream the source. Fig. 7 shows the concentrations of the PM emissions within $2 \mathrm{~km}$ from the source that is expected to result from the following units: SSP, GSSP, GTSP, DAP, PS DCP, NPK, $\mathrm{H}_{2} \mathrm{SO}_{4}$ and $\mathrm{H}_{3} \mathrm{PO}_{4}$. The concentration of the emitted $\mathrm{NH}_{3}$ is $0.71 \mathrm{mg} / \mathrm{m}^{3}(1.42 \%$ of Allowed Limit) at $0.5 \mathrm{~km}$ downstream the source point, and it decreases to $0.45 \mathrm{mg} / \mathrm{m}^{3}(0.9 \%$ of Allowed Limit) at $1 \mathrm{~km}$ and $0.19 \mathrm{mg} / \mathrm{m}^{3}(0.38 \%$ of Allowed limit $)$ at $2 \mathrm{~km}$, downstream the source. 


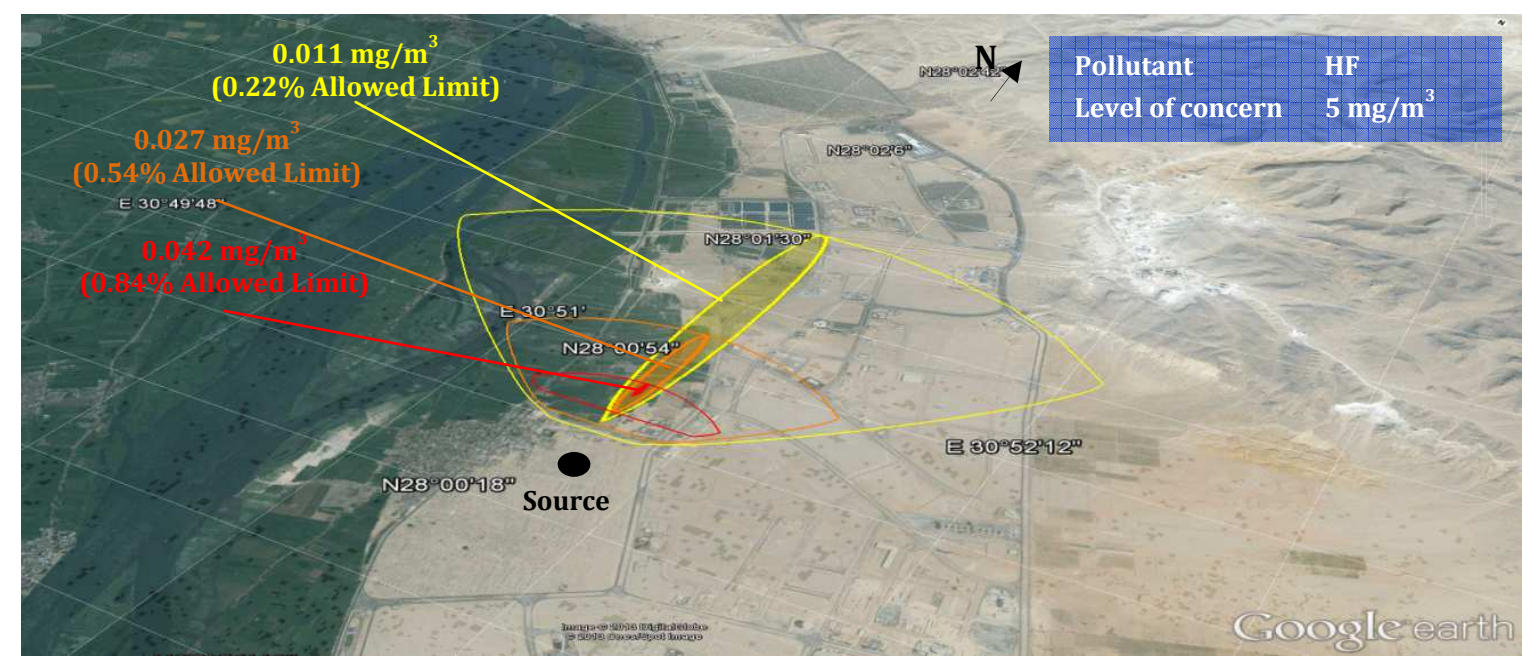

Fig. 3 Concentrations of the HF emission at $0.5 \mathrm{~km}, 1 \mathrm{~km}$ and $2 \mathrm{~km}$ downstream the source at worst case scenario

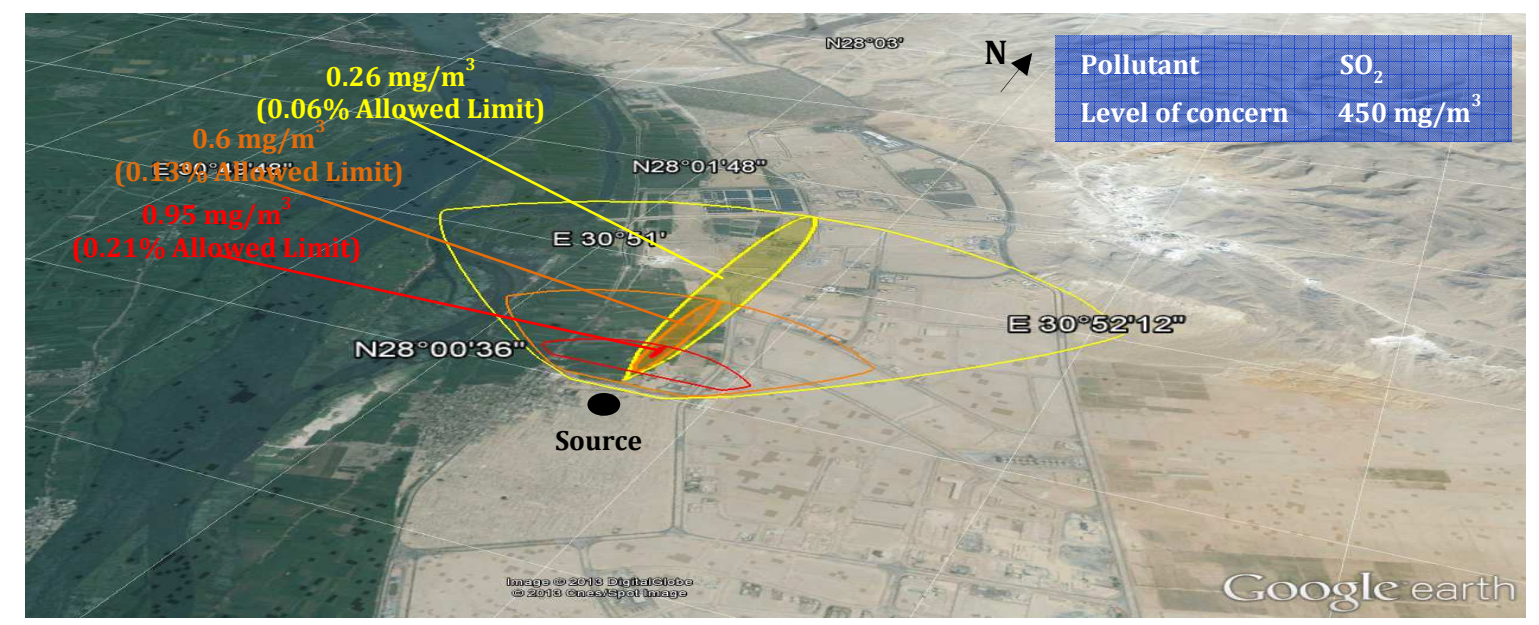

Fig. 4 Concentrations of the $\mathrm{SO}_{2}$ emission at $0.5 \mathrm{~km}, 1 \mathrm{~km}$ and $2 \mathrm{~km}$ downstream the source at worst case scenario

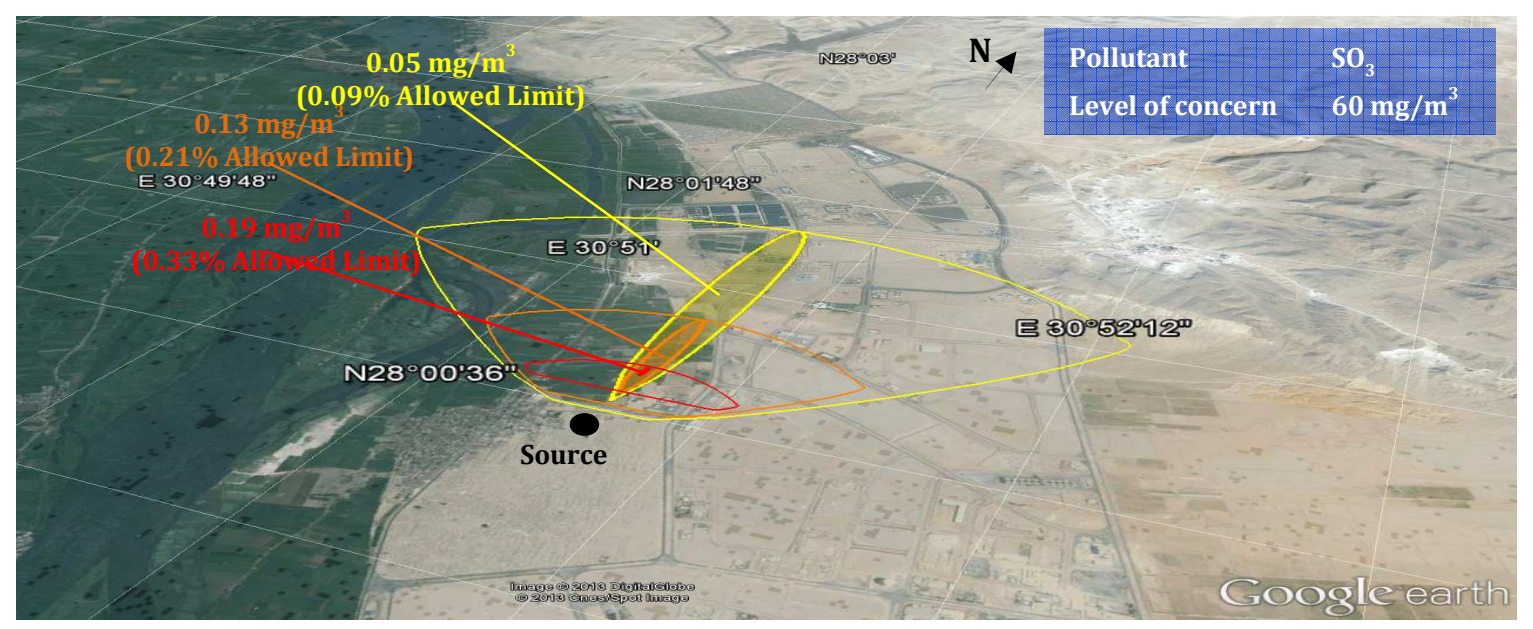

Fig. 5 Concentrations of the $\mathrm{SO}_{3}$ emission at $0.5 \mathrm{~km}, 1 \mathrm{~km}$ and $2 \mathrm{~km}$ downstream the source at worst case scenario 


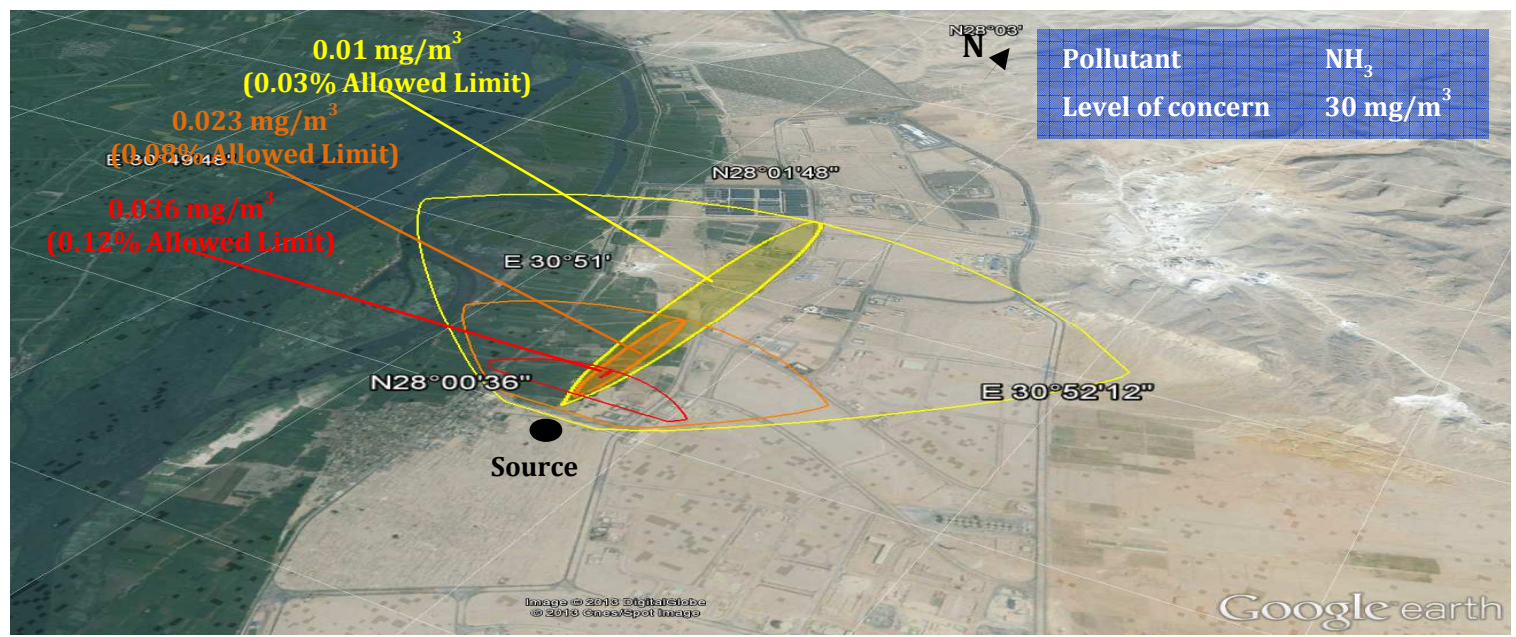

Fig. 6 Concentrations of the $\mathrm{NH}_{3}$ emission at $0.5 \mathrm{~km}, 1 \mathrm{~km}$ and $2 \mathrm{~km}$ downstream the source at worst case scenario

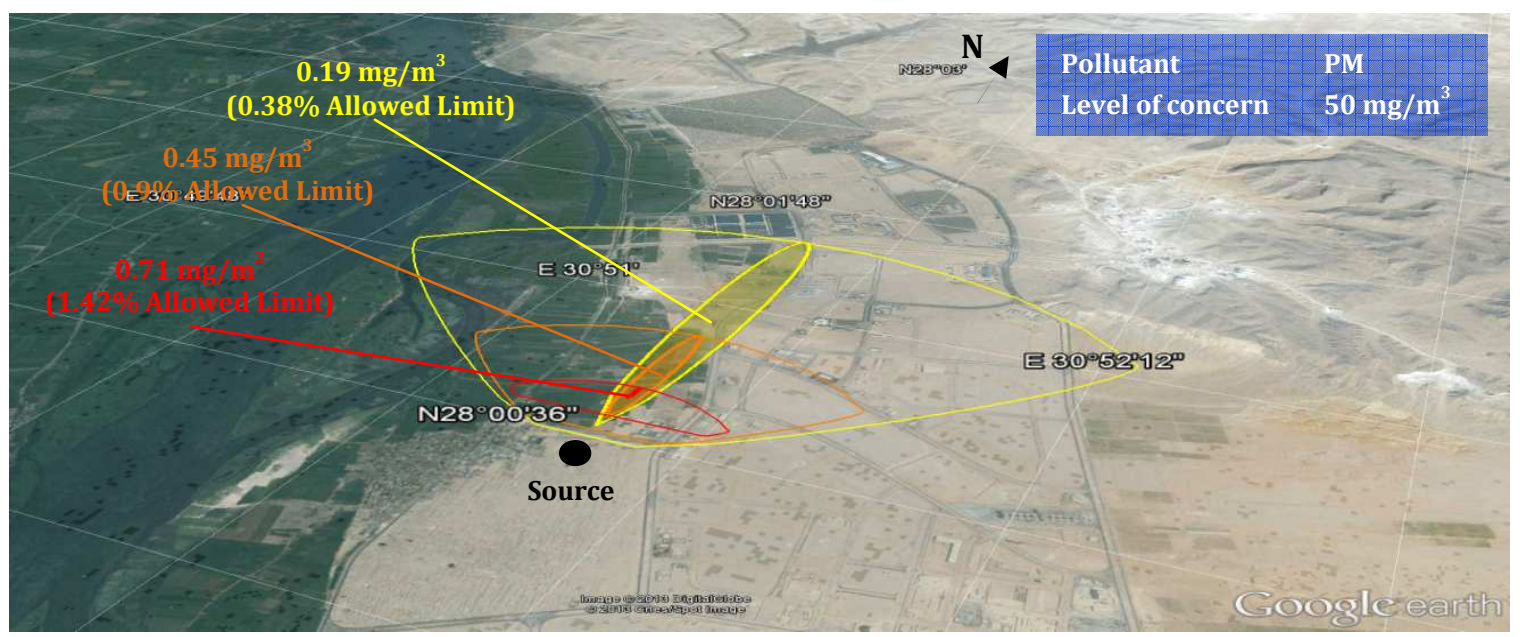

Fig. 7 Concentrations of the PM emission at $0.5 \mathrm{~km}, 1 \mathrm{~km}$ and $2 \mathrm{~km}$ downstream the source at worst case scenario

The concentrations of the different investigated pollution emissions from the proposed project at $0.5 \mathrm{~km}, 1 \mathrm{~km}$ and 2 $\mathrm{km}$ downstream the source are summarized in Table 4. The percent allowed of the concentrations of pollutant emission with respect to the allowed limit at $0.5 \mathrm{~km}, 1 \mathrm{~km}$, and $2 \mathrm{~km}$ downstream the source are shown in Fig. 8. In summary, the concentrations of the $\mathrm{HF}, \mathrm{SO}_{2}, \mathrm{SO}_{3}, \mathrm{NH}_{3}$, and $\mathrm{PM}$ emissions at $2 \mathrm{~km}$ downstream the source point are $0.011 \mathrm{mg} / \mathrm{m}^{3}$ $\left(0.22 \%\right.$ of the allowed limit), $0.26 \mathrm{mg} / \mathrm{m}^{3}(0.06 \%$ of the allowed limit), $0.05 \mathrm{mg} / \mathrm{m}^{3}(0.09 \%$ of the allowed limit), $0.01 \mathrm{gm} / \mathrm{m}^{3}\left(0.03 \%\right.$ of the allowed limit) and $0.19 \mathrm{mg} / \mathrm{m}^{3}$ $(0.38 \%$ of the allowed limit), respectively, at the worst case scenario, previously mentioned in Table 3 . Thus, all the emissions resulted from different activities in the proposed project are lower than the allowed limits specified by the Egyptian ministry of environment in Law 4/1994, and therefore the proposed project is not expected to cause any undesirable impacts on the surrounding environment. It is worth mentioning that the presented results are the expected concentrations at the worst case scenario. As, the wind speed and ambient air temperature are expected to be higher than those used in the modeling of the pollutant emissions, and the sky cloudiness is expected not to be fully covered all the time, which is expected to result in lower concentrations that those presented.

Table 4 Summary of the concentrations of the pollutant emission at $0.5 \mathrm{~km}, 1 \mathrm{~km}$, and $2 \mathrm{~km}$ downstream the source in $\mathrm{mg} / \mathrm{m}^{3}$.

\begin{tabular}{|c|c|c|c|c|c|}
\hline $\begin{array}{c}\text { Distance } \\
\text { downstream } \\
\text { the source }\end{array}$ & $\mathrm{HF}$ & $\mathrm{NH}_{3}$ & $\mathrm{SO}_{2}$ & $\mathrm{SO}_{3}$ & $\mathrm{PM}$ \\
\hline $0.5 \mathrm{~km}$ & 0.042 & 0.036 & 0.95 & 0.19 & 0.71 \\
\hline $1 \mathrm{~km}$ & 0.027 & 0.023 & 0.6 & 0.13 & 0.45 \\
\hline $2 \mathrm{~km}$ & 0.011 & 0.01 & 0.26 & 0.05 & 0.19 \\
\hline
\end{tabular}




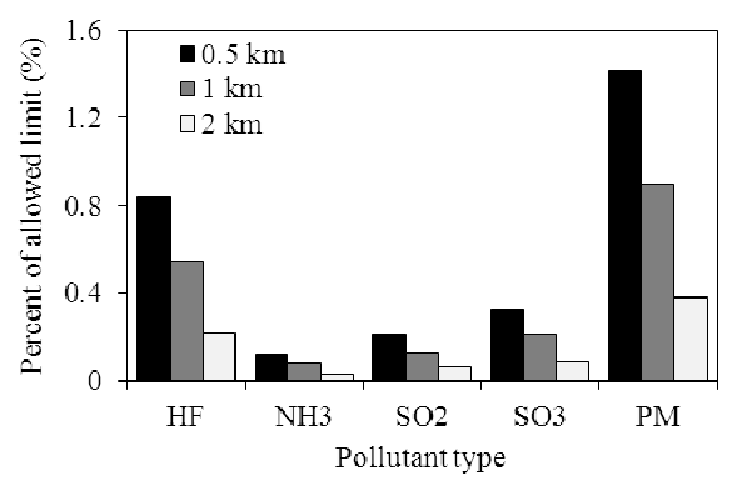

Fig. 8 Percent allowed of the concentrations of pollutant emission with respect to the allowed limit at $0.5 \mathrm{~km}, 1 \mathrm{~km}$, and $2 \mathrm{~km}$ downstream the source

\section{CONCLUSIONS}

Based on the project location, the studies commissioned show that there is no significant environmental negative impact of the proposed project, which means that more phosphate fertilizer production facilities could be established in similar locations. It is worth mentioning that possible adverse cumulative impacts should be considered. This could be achieved by a regional monitoring program for various components through the appropriate planning/environmental authorities.

\section{REFERENCES}

[1] The Arabic Union for Fertilizers, an Economic Report, 2012, Cairo.

[2] R.P. Prajapati and Rashmi singhai, "Impact Assessment of fertilizer Industry Waste on Environment", Journal of Environmental Science, Computer Science and Engineering \& technology (JECET) Vol. 1 No. 3, 311315, September-November 2012.

[3] Environmental Impacts Assessment of Phosphate Fertilizer Facility in Egypt, EEDC, Submitted to EEAA, Cairo - May 2013.

[4] C. Stern, Air Pollution. New York: Academic, 1976, Vol. 1.

[5] D. Sarokin and J. Schulkin, "The role of pollution in large-scale population disturbances," Environ. Sci. Technol., Vol. 26, No. 9, pp. 1694-1701, 1992.

[6] Environmental and Social Impacts Assessment of an Expansion project For Delta Fertilizer and Chemicals Industries Company, Egypt, Center of Researches and Environmental Studies, Cairo University, 2007.

[7] Bruno Andò, Salvatore Baglio, Salvatore Graziani, and Nicola Pitrone, "Models for Air Quality Management and Assessment", IEEE Transactions on systems, man and cybernetics - part C: applications and review, Vol. 30, No. 3, August 2000.

[8] Rafael Borge, Vassil Alexandrov, Juan Jose del Vas, Julio Lumbreras, Encarnacion Rodrguez, "A comprehensive sensitivity analysis of the WRF model for air quality applications over the Iberian Peninsula", Atmospheric Environment Vol. 42 (2008) pp. 85608574.

[9] L. Triolo \& A. Binazzi \& P. Cagnetti \& P. Carconi \& A. Correnti \& E. De Luca \& R. Di Bonito \& G. Grandoni \& M. Mastrantonio \& S. Rosa \& M. Schimberni \& R. Uccelli \& G. Zappa, "Air pollution impact assessment on agro ecosystem and human health characterization in the area surrounding the industrial settlement of Milazzo (Italy): a multidisciplinary approach", Environ. Monitoring Assess (2008) 140:191-209.

[10] Padma S. Rao A. Kumar M. F. Ansari P. Pipalatkar T. Chakrabarti, "Air Quality Impact of Sponge Iron Industries in Central India", Bull Environ Contam Toxicol DOI 10.1007/S00128- 008-9519-1, 2008

[11] Josef Brechiler, "Model assessment of air pollution in Prague", Dept. of Meteorology and Environmental Protection, Faculty of Math. and Phys., Charles University, Environmental Monitoring and Assessment 65: 269-276, 2000.

[12] Environmental Impacts Assessment of Proposed Expansion of 350 TPD Granulated Super Phosphate (GSSP) Plant at Mewar, Industrial Area, Madri, District- Udaipur, Rajasthan, 2010.

\section{BIOGRAPHIES}

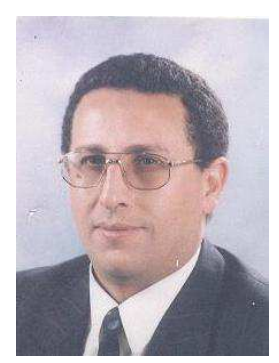

Dr. Hamdi A. Abdel Salam is a faculty member at the Mechanical Power Eng. Dept., Mansoura University, Egypt since 1992. He is an accredited consultant in mechanical design by the Egyptian Engineering Syndicate since 1999. 